\title{
Targeting Land Use Change to Enhance Multiple Environmental Benefits - A Mini Review
}

\author{
Mette Vestergaard Odgaard* and Tommy Dalgaard \\ Department of Agroecology, Aarhus University, Denmark
}

Submission: October 04, 2018; Published: October 24, 2018

*Corresponding author: Mette Vestergaard Odgaard, Department of Agroecology, Aarhus University, Denmark

\begin{abstract}
With the emergence of agriculture, human influence on natural ecosystems has accelerated and intense unsustainable land use is now one of the main factors causing eutrophication of both aquatic and terrestrial ecosystems. Using a holistic approach in agricultural management, as the term "Agroecology" implies, could potentially increase resilience and sustainability of a farming system. With a starting point in a previous published conceptual framework, describing how site-specific modulators can modulate the effect of drivers on human land use, we call attention to a targeted approach in land use change. The targeted approach describes a simple method to achieve multiple environmental benefits when selecting areas to initiate a certain land use change (exemplified with results from two previous studies). We review two main national goals: 1) To lower nitrogen loads by 13,000 t nitrogen/year and 2) achieve five mill ton dry-matter protein from grassland. Results indicate a potential to reach the main goals while simultaneously boosting nature areas and strengthening local environments. In conclusion, applying the targeted approach, or diversions of it, could potentially create multiple environmental benefits while reaching a main national goal.
\end{abstract}

Keywords: Agroecology; Targeted approach; Land use change; Multiple environmental benefits; Nature; Nitrogen

\section{Introduction}

Earth's resources have enabled and maintained human population growth through millennia, first supporting hunters and gatherers and later supporting farmers and herders [1] With the establishment of permanent agriculture approximately 10,000 years ago [1], human influence increased and has now outpaced the importance of climate as a driver of land cover patterns and dynamics [2,3]. This intensification has led to e.g. eutrophication of both aquatic and terrestrial ecosystems and an overall tendency towards increased fragmentation or complete homogenization of the cultural landscape [4-6] and of small natural and semi-natural areas $[7,8]$. The existence of such areas is crucial for maintaining high levels of biodiversity [9-12] and for supporting the sustainable provisioning of ecosystem services $[13,14]$ and landscape multifunctionality [14]. Hence, past and present-day research focusing on sustainability should circulate on how to achieve sustainable, and profitable, agriculture while simultaneously maintaining full function of surrounding ecosystems and - multiple environmental benefits. Applying a holistic approach in agricultural management and implement theory form ecology into agronomy could increase resilience and sustainability of a farming system - a term referred to as "Agroecology" [15-17]. Over the last 4 decades, the term "Agroecology" has been manifested not only in science but also as an agricultural practice near the farmer [18], and in light of the increasing human population, attention on how to entangle agriculture and nature conservation is needed to reassure a more sustainable resource use.
Here, we use the Danish region to argue the potential to achieve multiple environmental benefits while changing agricultural practice. We describe a targeted approach to detect areas, which should be the first to undergo a certain land use change (from intense agriculture to set aside [19] and from cereal to grassland [20] based on local environments characteristics and thereby how to strengthen the complete agro-ecological system while taking spatial varying relationships between driver and response into account, as described from the conceptual framework in Odgaard et al. [21].

\section{Results and Discussion}

For the Danish region, area scarcity and agricultural nutrientsurplus has been put forward as two of the main threats towards biodiversity and nature persistence [22], and Denmark has a national goal to reduce coastal $\mathrm{N}$ loads by 13,000 $\mathrm{t}$ nitrogen (N)/year [23]. At the same time, promising methods to derive protein from grass, as a substitute for protein derived from soya imported from the tropics, encourage methods to identify where to grow this new grassland [24]. Hence, the two main goals assessed in this review are:

a) To lower $\mathrm{N}$ loads by 13,000 $\mathrm{t} \mathrm{N} /$ year and

b) Achieve five mill ton dry-matter protein form grassland.

We adopt the framework described in Odgaard et al. [21] to increase attention on how to gain environmental benefits from land-use change due to spatial variations in local environmental 
variables using a targeted approach. The framework [21] consists of three parts: 1) the effects of geophysical constraints and sociotechnical drives on land use (part 1), how this effect is shaped by site-specific modulators (part 2), and eventually causing direct land use and new land cover patterns (part 3). Here, we only focus on the socio-technical drives in the framework.

\section{The targeted approach}

The targeted approach developed in Odgaard et al. [19] illustrates how a national goal describing quantities can be achieved while obtaining both agricultural optimizing and multiple environmental benefits. The approach is rather simple and easy applicable to other regions with the sufficient amount of geographical data. The method function on a dataset where each row describes the smallest area unit e.g. watersheds, municipalities, or fields. Each unit should hold information (attributes) on how much of the national goal is reached by conducting a specific land use change, and a quantitative measure of the environmental benefit/s following this change. The national goal-value is summed in a stepwise manner, counting the unit with the highest environmental benefit first, until the goal is reached. The number of units to undergo a certain land use change can be visualized in geographic information systems and local landscape characteristics can be calculated depending on available data.

\section{Application of the targeted method}

Two previous studies from the Danish region have highlighted potential benefits from using the targeted approach to initiate land use change: one considering where to initiate set aside with the main purpose being $\mathrm{N}$ mitigation while gaining natural and sociotechnical benefits [19], and another considering where to initiate grassland production with the main purpose to produce protein dry-matter while gaining environmental and natural benefits [20] (Figure 1).

In the first study [19], farmland to set aside were selected by targeting for areas with a high coastal $\mathrm{N}$ load, amount of surrounding nature, and soil value. Results indicate, contrary the expectation, that it is cheaper to target for surrounding nature compared to soil value due to changes in affected area-size. Furthermore, multiple benefits can be achieved when targeting set-aside for a variable describing a combination of $\mathrm{N}$ load, nature and soil value, if willing to convert $4 \%$ more land. In the other study from the same region [20], the rational was to increase local grassland-production and thereby decrease import of protein derived from soya, which is a rather unstable process $[25,26]$. Results reveal that up to $60 \%$ (7.800ton N/year) of the national $\mathrm{N}$ reduction goal can be reached by targeting conversion of cereal to grassland production towards areas whit highest $\mathrm{N}$ load. Simultaneously, grasslands over cereals can benefit local nature areas by boosting surrounding nature since grasslands are more extensively managed resulting in a higher biodiversity value than cereals [27]. Hence, national goals to lower $\mathrm{N}$ or boost existing nature can affect how humans decide to utilize the land and this effect can be modulated by site specific $\mathrm{N}$ loads, soil values, or amount of surrounding nature (Figure 1).

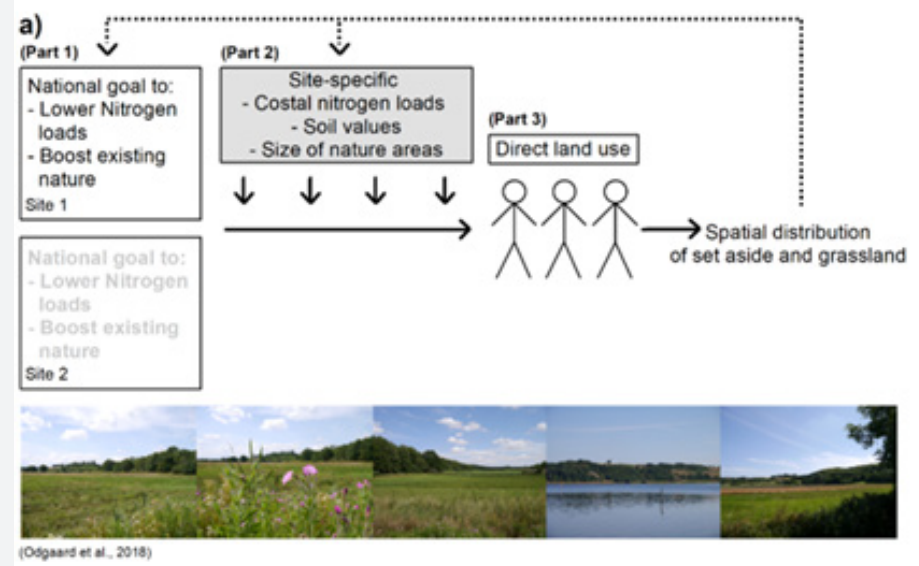

Figure 1: Conceptual framework as from Odgaard [22] exemplified with results from Odgaard [20,21]. The effect of the sociotechnical drivers (described as the two national goals: 1) to lower coastal nitrogen (N) loads by 13,000 ton N/yr and 2) boost existing nature areas) on land use (part 1) is shaped by site specific modulators (described as costal $\mathrm{N}$ loads and size of nature areas) (part 2) causing spatial distribution of land cover patterns (described as converting from agricultural land to set aside or from cereal production to grasslands (part 3). Bold text indicates high importance in a site and grey text indicate low importance in a site. Pictures are of a typical Danish lowland agricultural landscape describing set aside, grasslands, forest and fjords (Mette Vestergaard Odgaard [23].

\section{Conclusion}

Diverse demands for natural resources increase attention on how to create and sustain multifunctional landscapes. We describe a targeted approach to include other factors than the main purpose when shifting land use practice. Increased understanding of the factors that shape land-cover patterns could potentially help build a more sustainable agricultural system [28], which is a central issue for landscape ecology, biodiversity conservation, landscape planning, and studies in food production and human food security. Implying the targeted 
approach enables evaluation of possible costs and benefits both environmental and social - resulting from certain land use change prior to the actual conversion.

\section{Acknowledgement}

Thanks to support from Innovation Fund Denmark via the dNmark.org Research Alliance, and the EU Commission funded NitroPortugal, H2020-TWINN-2015 coordination and support action n. 692331.

\section{References}

1. Smith BD (1995) In search of origins. In Smith BD (Ed) The Emergence of Agriculture. WH Freeman and Company, New York and England pp. $1-13$.

2. Rull V, González Sampériz P, Corella J, Morellón M, Giralt S (2011) Vegetation changes in the southern Pyrenean flank during the last millennium in relation to climate and human activities: the Montcortès lacustrine record. Journal of Paleomlimnology 46(3): 387-404.

3. Reitalu T, Seppa H, Sugita S, Kangur M, Koff T, et al. (2013) Long-term drivers of forest composition in a boreonemoral region: the relative importance of climate and human impact. J Biogeogr 40: 1524-1534.

4. Fasona M, Omojola A (2009) Land cover change and land degradation in parts of the southwest coast of Nigeria. Afr J Ecol 47(1): 30-38.

5. Gao J, Li S (2011) Detecting spatially non-stationary and scaledependent relationships between urban landscape fragmentation and related factors using Geographically Weighted Regression. Appl Geogr 31: 292-302.

6. Kadlecova V, Dramstad WE, Semancikova E, Edwards KR (2012) Landscape changes and their influence on the heterogeneity of landscape of the South Bohemian Region, the Czech Republic. International Journal of Sustainable Development \& World Ecology 19: 546-556.

7. Monteiro AT, Fava F, Hiltbrunner E, Della Marianna G, Bocchi S (2011) Assessment of land cover changes and spatial drivers behind loss of permanent meadows in the lowlands of Italian Alps. Landscape Urban Plann. 100(3): 287-294.

8. Odgaard MV, Moeslund JE, Bøcher PK, Dalgaard T, Svenning JC (2013) The relative importance of geophysical constraints, amenity values, and farm-related factors in the dynamics of grassland set-aside. Agric Ecosyst Environ 164: 286-291.

9. Henderson IG, Cooper J, Fuller RJ, Vickery J (2000) The relative abundance of birds on set-aside and neighbouring fields in summer. J Appl Ecol 37: 335-347.

10. Kleijn D, Baquero RA, Clough Y, Díaz M, Esteban J, et al. (2006) Mixed biodiversity benefits of agri-environment schemes in five European countries. Ecol Lett 9: 243-254.

11. Devictor V, Jiguet F (2007) Community richness and stability in agricultural landscapes: the importance of surrounding habitats. Agric Ecosyst Environ 120(2-4): 179-184.

12. Winfree R, Aguilar R, Vázquez DP, LeBuhn G, Aizen MA (2009) A metaanalysis of bees' responses to anthropogenic disturbance. Ecology 90: 2068-2076.
13. Beier C, Patterson T, Chapin FS (2008) Ecosystem services and emergent vulnerability in managed ecosystems: a geospatial decisionsupport tool. Ecosystems 11: 923-938.

14. Mastrangelo ME, Weyland F, Villarino SH, Barral MP, Nahuelhual L, et al. (2014) Concepts and methods for landscape multifunctionality and a unifying framework based on ecosystem services. Landscape Ecol 29(2): 345-358.

15. Francis C, Lieblein G, Gliessman S, Breland TA, Creamer N (2003) Agroecology the Ecology of Food Systems. J Sustainable Agric 22: 99118.

16. Dalgaard T, Hutchings NJ, Porter JR (2003) Agroecology, scaling and interdisciplinarity. Agriculture, Ecosystems \& Environment 100(1): 39-51.

17. Gliessman SR (2006) Agroecology the Ecology of Sustainable Food Systems. CRC Press USA.

18. Wezel A, Bellon S, Doré T, Francis C, Vallod D, David C (2009) Agroecology as a science, a movement and a practice. A review Agron Sustain Dev.

19. Odgaard MV, Olesen JE, Børgesen CD, Svenning JC, Dalgaard T (2018b) Targeted set aside a Danish case study on multiple benefits from reduction of nitrogen loads to aquatic environments. Submitted.

20. Odgaard MV, Knudsen MT, Hermansen JE, Dalgaard T (2018a) Targeted grassland production - a Danish case study on multiple benefits from converting cereal to grasslands for green biorefinery. Submitted.

21. Odgaard MV, Dalgaard T, Bøcher PK, Svenning J (2018c) Site-specific modulators control how geophysical and socio-technical drivers shape land use and land cover. Geo Geography and Environment 5.

22. Høye TT, Ejrnæs R, Dalgaard T, Svenning J, Topping CJ (2012) Hvordan sikrer vi agerlandets biodiversitet? In Hans Meltofte (Ed) Danmarks Natur Frem Mod 2020. Det Grønne Kontaktudvalg c/o Danmarks Naturfredningsforening, p. 49-54.

23. Ministry of Environment and Food of Denmark (2016) Vandområdeplan 2015-2021 for Vandområdedistrekt Jylland og Fyn.

24. Hermansen JE, Jørgensen U, Lærke PE, Manevski K, Boelt B, et al. (2017) Green biomass proteing production through bio-refining 93 3-72.

25. Fearnside PM (2001) Soybean cultivation as a threat to the environment in Brazil. Environ Conserv 28: 23-38.

26. Castanheira ÉG, Freire F (2013) Greenhouse gas assessment of soybean production: implications of land use change and different cultivation systems. Journal of Cleaner Production 54: 49-60.

27. Knudsen MT, Hermansen JE, Cederberg C, Herzog F, Vale J, et al. (2017) Characterization factors for land use impacts on biodiversity in life cycle assessment based on direct measures of plant species richness in European farmland in the Temperate Broadleaf and Mixed Forest' biome. Science of the Total Environment 580: 358-366.

28. Levin G, Jepsen MR (2010) Abolition of set-aside schemes, associated impacts on habitat structure and modelling of potential effects of cross-farm regulation. Ecol Model 221: 2728-2737. 


(C) This work is licensed under Creative
Commons Attribution 4.0 License
DOI: 10.19080/IJESNR.2018.15.555905

\section{Your next submission with Juniper Publishers will reach you the below assets}

- Quality Editorial service

- Swift Peer Review

- Reprints availability

- E-prints Service

- Manuscript Podcast for convenient understanding

- Global attainment for your research

- Manuscript accessibility in different formats ( Pdf, E-pub, Full Text, Audio)

- Unceasing customer service

Track the below URL for one-step submission https://juniperpublishers.com/online-submission.php 